\title{
KEY WOMEN COMPETENCES AND NEW QUALITY OF MANAGEMENT - CASE OF THE PROJECT WIN
}

\author{
KLJUČNE ŽENSKE KOMPETENCIJE I NOVA \\ KVALITETA UPRAVLJANJA - SLUČAJ PROJEKTA WIN
}

Ing. Renata Stasiak-Betlejewska, PhD.

Faculty of Management, The Czestochowa University of Technology,

Czestochowa, Poland/Poljska

E-mail: renata.stasiak-betlejewska@wz.pcz.pl

UDK/UDC: $378.014 .61(438)$

JEL klasifikacija/JEL classification: M12, M50

DOI: $10.30657 / \mathrm{hdmk} .2020 .42$

Pregledni članak/Review

Jezik/Language: Engleski/English

\begin{abstract}
In the conditions of growing uncertainty and rapid changes, modern business needs a new management model. The old one, based on a rigid hierarchical structure, relied mainly on competition and the pursuit of individual successes. However, the challenges and problems faced by today's companies, due to their complexity, require a new approach. Empathy, communication skills, openness to others and selfawareness are key elements in building the leadership position of the 21st century. These are so-called "oft"competences, usually perceived as feminine." Paper presents results of research on key women competences in the enterprises management and it includes also short presentation of the scientific project related to collaboration with industry on key competences called WiN (Women in NetWork).
\end{abstract}

Key words: quality, competence, management.

\section{INTRODUCTION}

In recent years, the creativity of employees and the resulting attitude of openness to change, innovation and entrepreneurship have been identified as the main development factor and source of competitive advantage in contemporary organizations. ${ }^{1}$ These are one of the most frequently indicated competences as the basis for making changes in enterprises.

An employee's competence is his behavior or behavior in a particular situation. The level of competence is affected by the external environment in which the person is, the organizational culture of the company in which the person works and the employee's selfawareness. Competences include: ${ }^{2}$

- a set of features that enable you to complete work-related tasks,

\footnotetext{
${ }^{1}$ Anna Kałwa-Rojczyk, Funkcjonowanie turkusowych organizacji w kontekście kompetencji pracowniczych, Studia i Prace WNEIZ US nr 51/2, 2018, pp. 45.

${ }^{2}$ Mirosław Kot, Kompetencje menedżera, Wydawnictwo Helion, Gliwice, 2018, pp. 11-12.
} 
- employee behavior and the effects of his activities related to a specific job position,

- knowledge, skills, attitude.

Competencies are developed based on innate qualities or features formed during the last years of work. In turn, the tendency is predisposed to certain behaviors that help develop competencies.

There is a division into soft and hard competences, where soft refers to personal skills, character traits, who we are, how we perceive the environment and how we operate. Hard competences are our specific skills that can be called technical (knowledge of languages, laws, procedures, computer skills, knowledge of management processes or the construction of a specific device).

The most important properties of competence: measurability, variability, relationship with tasks. In order to effectively manage competences, their monitoring should be ensured established in accordance with specific principles adopted in the organization of the competency model. It has to do in particular processes such as recruitment and selection of job candidates, employees create evaluation system, analysis of training needs, coaching needs analysis, evaluation and effects of the training session, decisions about layoffs. Increasing awareness of competence development can be divided into stages:: ${ }^{3}$

1. Unconscious competence (I don't know what I can't).

2. Conscious incompetence (I know what I can't and I want to learn it).

3. Conscious competence (I can but I must be focused to do it right).

4. Unconscious competence (I can and I am good at it, I do not think about doing it right - I just do it habitually).

Over the years, the approach to key managerial competencies has changed. Currently, trends such as:

- competences and work-life balance,

- diversity,

- turquoise organizations.

Analysing the relationships of competences and work-life balance, one considers the motivation to work on their competences in the context of obtaining energy: physical, mental, mental and spiritual, and above all work and leisure.

Creating a competency model (book of competences) is associated with the need to create in each organization a set of competences for specific positions, which makes up the book of competences. The competency model should be covered by a specific creation strategy based on: company strategy, standards, competency management and scaling methods, employee competence assessment, competence gap analysis, and the evolution of competency development activities. ${ }^{4}$ During creating a competency model, a question should be asked regarding the organization's priorities in market activity and the entity that is to create this model (HR department or external entity).

The competency model should include the following elements: competence name, definition of competence (examples of behaviors that are associated with it), examples of omissions (explanation of what an employee in a given position should not do, what roles should not be involved, etc., competence scaling).

The paper analyzes the position of women in organizations, the impact of women's managers' competencies on the development of organizations in the context of changing the quality of management. Also presented here is an original proposition of a key competences model that will be implemented in one of the automotive industry companies as part of the

\footnotetext{
${ }^{3}$ Ibid.

${ }^{4}$ Ibid.
} 
WiN (Women in NetWork) project. Research findings presented in the paper were also one of the basis for creating the project WiN since there is significant need in organization to find appropriate solutions that can not only suport the management process in the organization but also can influence on the quality of management in new economy conditions.

\section{KEY COMPETENCES OF THE FUTURE}

In the conditions of growing uncertainty and rapid changes, modern business needs a new management model. The old one, based on a rigid hierarchical structure, relied mainly on competition and the pursuit of individual successes. However, the challenges and problems facing today's companies, due to their complexity, require a new approach.

Worldwide research shows that women as leaders tend to cope much better with economic and social transformation, primarily due to their willingness to cooperate with others and adaptability. This is their key advantage in today's fast-changing business environment. Seeing in advance the warning signals and problems threatening the team or organization, they can react in advance.

Women are also more cautious, and in conditions of high pressure and overload, their empathic, intuitive leadership is more beneficial for the team and the company.

Women managing a company or team more often and more willingly react to the comments of the environment and are willing to make greater concessions. This openness and willingness to cooperate is part of the emotional intelligence that women usually have to a much greater extent than men. A number of studies have shown that a high level of emotional intelligence of leaders translates into business efficiency of enterprises.

These "soft" competences directly influence the company's hard results, but also significantly improve its daily functioning. Women as bosses communicate with their team more efficiently and set goals for it. They also skillfully build relationships between various teams and company departments, and support group collaboration. Because they are usually better at analyzing and communicating problems, they are more effective in project management, and due to better communication skills and negotiation skills are great at dealing with clients. Thanks to better developed empathy, women in managerial positions can also effectively support others in development, inspire and motivate them to act.

It is clearly visible how comprehensive support for organizations can be women in managerial positions. That is why it is so difficult to understand that in many communities and cultures it is still underestimated and does not support women in business. Ladies in high positions often feel a lot of pressure from the environment. They must constantly prove their value in the organization and are afraid to make a mistake. Because they lack a sense of security and stability. In a male-dominated environment, much more is required of women to get or hold an analogous position, and their knowledge and experience are constantly being questioned. They cannot rest on their laurels and enjoy their achievements, because they always have to take the initiative.

In the PwC report on the features and competences of future leaders, leaders from Google and Skanska pointed out the most important problems in this context. ${ }^{5}$

Along with global changes and social and generational changes taking place, the current business paradigms have also been modified, the portrait of an effective leader has changed. The market needs a new leadership competency model today. In the search for competences of the future, a group of nearly 200 senior management managers were analyzed: owners, company presidents, board members and representatives of other management

\footnotetext{
${ }^{5}$ Przywództwo przyszłości Polski lider gotowy na zmiany? Raport PwC, Google. Skanska, 2019.
} 
positions. $50 \%$ were women. The study covered four main pillars of leaders' activities: leadership, actions in the area of strategy, relations with the external environment and the use of new trends and technologies. Researchers asked not only what is important for leaders in the areas of values, skills, management and communication, but also whether their ideas about effective leadership are reflected in their actions.

The PwC report covers three key areas and shows their impact on management style: technological progress, digital revolution and social change. For companies and their leaders, not only the multitude of aspects that they have to face in each of these areas, but also the pace of change is becoming a challenge. The leader of the future is a person who not only notices these changes, but is also able to overtake them, thus creating an advantage on the market. In a world where changes occur so quickly and so often the leader will be the one who will be able to manage change best.

The digital revolution, the constantly increasing accessibility of the Internet and the speed of connections, the transfer of part of life to social media, the use of smartphones as small command centers, and above all the emergence of a new generation (Millennials), people for whom the use of technology is already a lifestyle, that the way we communicate, collect and search for information, work, and contact the client completely changes. Digital transformation is the most important business challenge of leaders in the coming years. Probably also the most difficult in their career. There are no standards and methodologies tested on many implementations. You need to take risks that determine the future of a strategic company. Many leaders in this process focus on aspects related to the implementation of technology, while digital transformation is primarily an element of cultural transformation.

In the raport PwC key competences and skills, that are essential for future leaders, have been identified:

1. Openness and flexibility. The enemy of the companies of the future will be habits, patterns and rigid adherence to the rules. The leader of the future must be able to combine different management models. When you need to talk and listen, she collects feedback, but when the situation requires it, she can quickly make a difficult and sometimes risky decision. He is open to different points of view - he sees potential, not a threat, in a variety of opinions and views. Thanks to this, he is able to build a team, choosing people according to their talents, and not according to whether the co-worker has the same opinion as his boss.

2. Intuition based on knowledge, data and experience. To detect the current trends, there is a need to actually follow. To overtake them is intuition based on strong knowledge and extensive experience. In turn, knowledge and experience combined with flexibility help the trend understand, incorporate it into the strategy and then implement it. The ability to analyze data is one of the key management competences today. It allows not only to puncture the upcoming trends, but also to make better business decisions. The PwC report shows that due to insufficient ability to analyze, companies in Poland use only $12 \%$ of their data. It is worth remembering that their poor quality reduces operating revenues by up to $35 \%$.

3. Supporting diversity and building interdisciplinary teams. Success in the modern economy depends primarily on people: on their innovation, creativity, initiative and ability to cooperate. It is worth promoting diversity in companies. Locking ourselves in the hermetic world of sex, beliefs and stereotypes harms not only ourselves, but above all business. There is no easier way to waste talent. For a leader, managing such a band is a challenge, because more than a boss he must be a conductor who can tune various musicians with him. To succeed in this field, he must not only be able to give orders and enforce, but also listen carefully and 
delegate tasks. Teams are built in such a way that the people who make them up complement each other in their competences and how to solve problems. Thanks to this, the organization is able to develop solutions faster and more sustainably.

4. Multi-channel and careful communication. By 2020 , approximatelly $75 \%$ of the world's employees will be Millennials generation. They are people who feel comfortable in the world of technological innovation. They are also usually open to changes, much more flexible than their predecessors. Independence is important to them. They will be a challenge both as employees and as clients. Therefore, the leader of the future must be prepared to force changes in the way of communication. For Millenials, functioning in an open environment, in a culture based on trust, joint decision-making and mutual respect is of key importance. For them, the leader will be a person focused on conversation, listening, dialogue - ready to include employee ideas in the strategy of action.

5. A Focus on values. Changes occurring in society, the emergence of Millenials, for whom the opportunity for development, passion and values at work are sometimes more important than promotion and the amount of remuneration force employers to focus more on values. They will retain talents in the company. That is why quality management will replace management by objectives, authoritarianism will be supplanted by openness and trust, and innovation will replace attachment to the status quo. The values will be knowledge, ethics and relationships. Once company values were implemented in such a way that people were told: choose what values you want to have in the company and we will respect them all.

The global trend is currently moving away from management by goals, focused almost exclusively on achieving fast, but not always long-term business results. This method has been and is used in many enterprises to continuously increase efficiency. Individual goals are constructed so as to combine into a coherent whole and support the development of the entire enterprise. Under the influence of the tendencies described earlier, such as the expectations of new employees, the desire to stand out in the market or the widespread dissemination of the practice of social responsibility, we are increasingly witnessing a departure from the model of management by goals. Gradually, its place is taken by quality management, in which a holistic view of the company and its environment is important. Constant improvement of employees' qualifications and teamwork are fundamental in this concept. Customer satisfaction leads to success, achieved through a pro-quality and process approach.

A decisive step towards building quality-oriented organizations is the fact that in most companies, formal feedback systems are created. Teamwork plays a fundamental role in this concept, and information systems are conducive to improving work culture and understanding mutual expectations in teams. Although they are currently mainly used as a tool to support the achievement of business goals, there is already a group of leaders who treat them as employee appreciation. As the results of our study indicate, it is women who strongly emphasize the aspect of motivating to achieve goals. This raises the question of whether this perception of feedback by ladies is the result of internal pressure that they impose on themselves? "For leaders, motivating others is on the one hand a method of achieving their high standards, which they often set themselves. On the other hand, women are by nature more socially sensitive, often treating the company as "their family". It's a kind of responsibility for the whole organization, for a team of people, but also for individual people. Just like the "herd keeper" who strives to make them healthy, thriving and achieving excellent results. It also translates into the way investment decisions are made. Women, when investing, are guided by their internal personal values more often than men.

The way to build a company managed by quality is also a lot more weight, which leaders attach to soft competences (social skills). $85 \%$ of respondents declared that they are 
important to them. The competences needed in operational management turned out to be the most valuable: planning, ability to motivate, courage and teamwork. Those listed as least important were: conflict management, influencing others, and personal effectiveness. There is a discrepancy between the declarations and the actual actions of the leaders.

\section{WOMEN POSITION IN THE ORGANIZATIONS}

Most people do not have sufficient self-awareness and an open mind to completely analyze the difficult situation. That is why the unpredictability and change that are characteristic of modern business are fear and anxiety. The role of leaders is then to support their employees in solving these problems. Women are better in this role as leaders because care for others, empathy and intuition they come naturally to them. In more traditional, patriarchal cultures, the modern management model based on such "feminine" values is often underestimated. This is a short-sighted strategy because the old model has stopped working and the role of soft competence in management is increasingly appreciated. Despite being called 'soft', these traits definitely belong to the strengths of women in managerial positions and determine their success. Reports and analyzes, as well as feedback from colleagues and management, show that women as leaders are rated higher than men, and the higher the position, the greater the difference in favor of women.

The "Manager in Stilettos" report, prepared by the HRK S.A. personnel consultancy company, still addresses the current topic of the role of women in business. Its purpose was to examine women in high positions in companies operating throughout the country in terms of their presence in the business world. The study was conducted using the CAWI method. The report was based on an analysis of the results of the study, which was conducted in 2019 on a group of 137 women. Participants are professionally active in managerial positions $(69.6 \%)$ hold the position of manager / manager, $25 \%$ director, $5.4 \%$ act as managing director / president. As many as $62 \%$ of the surveyed managers denied planning their careers, only $38 \%$ admitted that they had planned their career development towards the managerial position from the very beginning.

Success is very differently defined by women. Even in the professional field, it often means reconciling professional and private life, especially motherhood. Indeed, in Polish culture, where we tend to try to be a perfectionist in every field - professional, family - we want to develop, fulfill our passions - achieving relative balance is admirable. And yet women of success have mastered this art in prominent positions. That is why they are an inspiration for others. Very often they are also a huge support. According to the survey, $65.2 \%$ of organizations currently support women in developing their careers, but still a significant group of women do not feel this support. Regular assessment of work performed is also popular among organizations (35.9\%), however, survey participants indicate that it is not always an in-depth assessment of work, or is limited to annual or semi-annual assessments only. Unfortunately, women also indicate a lack of feedback.

Companies rarely have a clearly defined career path or mentoring in its planning. Women do not know what to do to get a promotion, there is a lack of clear communication in this regard, which gives rise to rumors about "promotions set up". Interestingly, women who perform managerial functions and do not have a team point to the disadvantage of this solution. The lack of a team prevents them from developing competencies in personnel management and leadership. Much is said about the promotion of women in the organization - their role in projects, their successes - women need it, because a good word adds wind in the sails, but also point to the disadvantage of too intrusive promotion of women in a company that can turn against them - showing them as mentally weak, unable to cope with stress, constantly in need 
of support. external training and courses $42.3 \%$ internal training and mentoring courses in career planning regular assessment of work performed clearly defined career path does not support $43.5 \% 9.8 \% 35.9 \% 10.9 \% 34.8 \%$ How is your organization supports women in development? The companies that do this most often offer the opportunity to participate in internal (43.5\%) and external (42.4\%) trainings and courses, but they are evaluated negatively, because they do not always meet the current needs of the participants or are not matched to the current position.

What should companies implement? According to the respondents, these are: training tailored to specific positions $(23 \%)$, mentoring (14\%) and clear promotion criteria $(13 \%)$. The subject of training was particularly deepened by the participants of the study - ladies would be interested in participating in training in communication, leadership, process simplification, self-confidence and assertiveness. Other recommendations include training tailored to the needs and career paths, mentoring, clear promotion criteria, coaching, promotion of women's achievements in the company, in-depth feedback, periodic job evaluation, competitions for managerial positions.

Despite the introduction of diversity policy by companies, we still meet a man more often than women in leadership positions. $71.7 \%$ of survey participants indicated that in their companies men dominate in senior positions, while $18.5 \%$ said the distribution is $50 / 50$. Only $9.8 \%$ of women noticed female dominance in this type of position. Despite the positive changes that have been observed, over $65 \%$ of women surveyed by us believe that gender is still a major factor in many companies. The reason is the so-called glass ceiling and the still existing belief that in selected industries women will fail, and the belief that women do not have the right qualifications to occupy a managerial position in the company.

A woman has many social roles, therefore she has a huge range of experiences that can be helpful in her managerial role. Typical female traits such as good organization, showing interest, motivating and inspiring, as well as empathy are extremely valuable. However, men are convinced that they are also indecisive and often succumb to emotions that are not indicated in business. When asked about what blocks them in their career development, the participants of our study most often indicated low self-esteem and lack of self-confidence and skills (39\%).

Women who notice the changes mainly indicate that employers are beginning to appreciate the competence and commitment and determination of women, in some companies consultations have also started, which should change in the organization globally to increase the participation of women in company structures, also a great impact on employee behavior has various types of policies, e.g. diversity policies.

In accordance to the $\mathrm{OECD}^{6}$, who continues to make gradual progress to improve female economic empowerment (the Women in Work Index provides our assessment of female economic empowerment in 2017 across 33 OECD countries), small gains to female economic empowerment, mainly the result of reducing the average gender pay gap and female unemployment rate, while performance on all other indicators remained broadly constant. Iceland and Sweden remain the top 2 performing OECD countries, while New Zealand joins the top three ranks for the first time since this Index was first published. Ireland and the Netherlands improved their ranks since last year owing to positive improvements across most of the indicators in the Index, and in particular the reduction in the female unemployment rate in the Netherlands. Since 2000, Luxembourg and Poland have made substantial improvements on the Index, as a result of a significant narrowing of the gender pay gap and a large reduction in the female unemployment rate, respectively.

Increasing the number of women in work could increase GDP across the OECD by over

\footnotetext{
${ }^{6}$ Jing Teow, Saloni Goel, Tara Shrestha Carney and Alex Cooper, Women in Work Index 2019 Turning policies into effective action, PwC, March 2019.
} 
US\$6 trillion. Analysis provides estimates of the broad order of magnitude of potential gains for each country from increasing female employment rates to match those of Sweden - a consistently top performer in our Index with a female employment rate of $69 \%$. Countries with relatively low female employment rates such as Greece, Mexico and Italy are likely to accrue the largest potential gains in percentage terms. Increasing the rate of female employment to those in Sweden could generate GDP increases of c.30\% for these countries. The economic benefit to the UK could be significant: - Increasing the female employment rate from $57 \%$ to that of Sweden $(69 \%$ ) results in gains of around $9 \%$ of UK GDP, or US $\$ 250$ billion (or $£ 178$ billion). Countries that exhibit a female employment rate close to Sweden's female employment rates are likely to generate a smaller boost in GDP; this includes the other Nordic countries like Norway and Finland, as well as Estonia.

China and India have made significant improvements in female economic empowerment, however there is room for further progress to promote gender equality and economic opportunity for women.

Figure 1. female economic empowerment in Chine and India

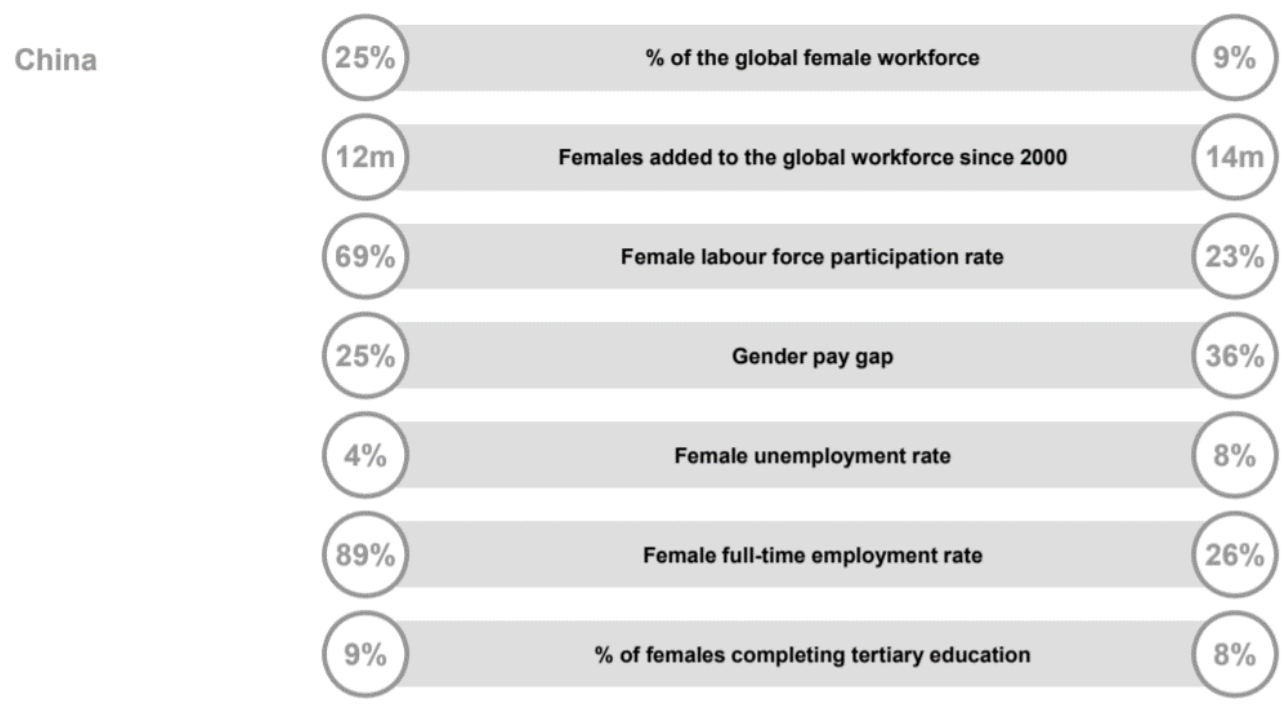

Source: OECD, Women in Work Index 2019. ${ }^{7}$

Women in China "hold up half the sky" with notable successes in the large number of female entrepreneurs and billionaires, but challenges remain. There remain obstacles that prevent women from taking full advantage of China's economic expansion but Chinese women have also enjoyed successes, particularly entrepreneurship opportunities. According to government data, more than a quarter of all entrepreneurs in China are women, and in 2017, Chinese businesswomen made up 56 of the world's 88 self-made female billionaires, making China one of the best places in the world to be a female entrepreneur. One of the key drivers behind China's female entrepreneurship success has been the growth of the digital economy and a thriving tech scene, comprising of sectors such as, e-commerce, AI and robotics. According to a report by the MSCI, out of 99 women who held chief executive positions in 2018, 17 of them were from Chinese companies, many of which were technology companies. The digital economy is perceived to have lower barriers to entry and a more gender-neutral

\footnotetext{
${ }^{7}$ OECD, Women in Work Index, 2019.
} 
environment compared to traditional sectors such as manufacturing and real estate. The growth of these sectors, combined with rising education levels has led to the digital economy becoming a popular path to work and wealth for women in China. With the greater involvement of female founders and leaders, Chinese tech firms are also fostering a more female-friendly work environment and culture, an area where OECD companies, including tech companies could learn from.

Nearly 9.4 million persons hold a managerial position in the European Union (EU): 6.0 million men (64\% of all managers) and 3.4 million women (36\%). In addition, women account for a little over one quarter of board members of publicly listed companies in the EU $(27 \%)$, and for less than one fifth of senior executives (17\%) in 2018. In other words, although representing approximately half of all employed persons in the EU, women continue to be under-represented amongst managers. Managers are mostly women only in Latvia The largest share of women among managerial positions is recorded in Latvia $(56 \%)$, the only Member State where women are a majority (56\%) in this occupation. It is followed by Bulgaria and Estonia (both 49\%), Poland and Slovenia (both 47\%), Hungary (43\%), Lithuania and Sweden (both 42\%), Ireland (41\%), and Slovakia (40\%). At the opposite end of the scale, women account for less than a third of managers in Luxembourg (15\%), followed by Cyprus $(23 \%)$, Czechia, Denmark, Italy and the Netherlands (all 29\%), Germany (30\%), as well as Greece and Austria (both 32\%). At EU level, about a third (36\%) of managers are women. The largest share of female board members in the largest publicly listed companies is recorded in France (44\%), followed by Italy and Sweden (both 36\%), Finland (35\%), and Germany (34\%). At the opposite end of the scale, women account for less than a fifth of board members in Estonia (8\%), Greece (9\%), Malta (10\%), Cyprus, Lithuania and Romania (all 11\%), Luxembourg (13\%), Czechia (14\%), Bulgaria and Hungary (15\%), Croatia (17\%), as well as in Ireland (19\%). At EU level, just over a quarter $(27 \%)$ of board members are women. Over the last five years, this share has increased by 9 percentage points $(18 \%$ in 2013$){ }^{8}$

The labor market in the European Union is increasingly friendly to women. The difference between the average hourly gross wages of men and women, according to Eurostat data, has been slightly decreasing since 2010 (17.1\% - 2010) and was 16\% in 2017. In Poland, 2017 saw a 7.2\% pay gap. - In the European Union (EU-28) member states, women only cover $36 \%$ of all managerial positions. The situation is even worse at higher levels $-27 \%$ of women are on the boards of the largest public companies, and $17 \%$ among those employed in managerial positions. ${ }^{9}$

According to the latest data presented in the $\mathrm{PwC}$ report, the Polish labor market is becoming more women-friendly. PwC experts analyzed the situation of women on the labor market in 33 countries of the Organization for Economic Cooperation and Development (OECD). The analysis took into account factors such as the gender pay gap, professional activity of both groups, the unemployment rate and full-time work. In the latest edition of the study Poland is $8^{\text {th }}$ in the ranking, i.e. one position higher than in 2016 and 11 higher compared to 2000. This is Poland's best result in the history of the survey since 2000. PwC experts emphasize that Poland's promotion This is the result of, among others, the gradual reduction of the pay gap in the remuneration of women and men and the decreasing unemployment rate among women.

Eurostat data shows that in Poland women constitute $21 \%$ of board members in major public companies. Although in the last five years this share has increased by $9 \mathrm{pp}$, it is still below the EU average (26.7\%). Eurostat also provided data on women's participation in senior

\footnotetext{
${ }^{8}$ Natalia Petrovova, Only 1 manager out of 3 in the EU is a woman ... ... even less in senior management positions, 43/2019.

${ }^{9}$ Rynek pracy, edukacja, kompetencje. Aktualne trendy i wyniki badań. Marzec 2019, Instytut Analiz Rynku Pracy Sp. z o.o.
} 
management. In Poland, their percentage is $13 \%$ and is one of the lowest share of women in managerial positions in comparison with other EU member states. In turn, Poland is a country where one of the largest shares of women in managerial positions was noted (46.84\%).

Interviews with managers show that other women, usually direct superiors, are the inspiration for gaining new qualifications and subsequent career levels. Unfortunately, the study is another that confirms the existence of a glass ceiling. Every year, the World Forum in Davos publishes Global Gender Gap. The latest report, from December 2018, shows that the differences between men and women in their position in society and in business, they will disappear in 108 years. But if you look only at economic issues - the differences will disappear in 202 years. Meanwhile, international research shows that the greater presence of women in managing organizations gives better financial results. Unfortunately, in Poland, due to the small number of public companies and the relatively small group of women in their authorities, it is difficult to conduct reliable research on the impact of diversity on financial results. Outside Poland, such research has been conducted for several years. ${ }^{10}$

\section{ANALYSIS OF PROJECT WIN IN KEY WOMEN COMPETENCES}

According to the list of competences of the future developed by the World Economic Forum (WEF), undertaking professional activity in economy 4.0 (so-called changing economy), based on short-term work, requires different characteristics and skills than on the traditional labor market, which in turn requires a different approach to educating staff than training employees for the needs of the traditional economy. Changes resulting from the functioning of societies in the 4.0 economy are quite revolutionary and cover many areas of activity - from technology to demographic and cultural changes.

Smooth change requires employees to be flexible and constantly adapting to new conditions. Changes resulting from global development on a global scale are called megatrends ${ }^{11}$ : technology development, i.e. digitization and ICT development, environmental changes, especially climate change and depletion of resources, demographic changes, in particular the increase in the global population and the aging of societies, as well as urbanization and geopolitical changes. One consequence of existing megatrends are rapid changes in the labor market.

Knowledge of key competences that will be important in the digital economy is very important in the process of educating future staff. Trend Compendium 2030 summarizes the key competences of the future:

- Social skills: an active role in social projects.

- Innovation and creative skills: comprehensive problem solving, analytical thinking, creative and systematic thinking.

- Technological skills: digital skills, including programming, digital responsibility and the use of technology.

- Interpersonal skills: interpersonal emotional intelligence, including empathy, cooperation, negotiations, leadership and social awareness.

- Personalized and independent learning: the transition from a system where learning is standardized to a system based on the different individual needs of each student and flexible enough to allow each student to progress at his own pace.

\footnotetext{
${ }^{10}$ Maria Bnińska, Kobiety w biznesie. Marzenia a rzeczywistość, Warszawa, maj 2019 r. Copyright by Fundacja Liderek Biznesu, 2019.

${ }^{11}$ Trend Compendium, 2030.
} 
- Available and inclusive learning: inclusion in a system where everyone has access to learning.

- Problem-based and collaborative learning: the transition from providing processbased content to projects and problems, which requires collaboration.

- Lifelong learning: improving existing skills.

Undertaking professional activity in such an environment requires different characteristics and skills than in a traditional labor market, which in turn requires a different approach to staff training than when training employees for the needs of a traditional economy.

The main goal of the project is to identify key competences that will be most relevant in the digital economy. Due to dynamic changes related to the 4.0 economy, employees must be flexible and constantly adapt to new conditions.

Dr. Eng. Renata Stasiak-Betlejewska, long-term academic teacher, coordinator of the international Erasmus + program at the Faculty of Management of the Czestochowa University of Technology, initiator and supervisor of the Erasmus + Manager student research club. Participant of the Lean in STEM mentoring program implemented by the PERSPEKTYWY Foundation in cooperation with Barbara Nowacka.

The mentoring project WiN (Women in NetWork) is the original idea of dr inż. Renata Stasiak-Betlejewska, who was born as an idea in 2018 as a result of talks with enterprises (partners of the aforementioned student circle) and the SIEMENS company with which Dr. Stasiak-Betlejewska made contact in 2017 by implementing the UNUSUAL WOMEN project at the POLITECHNICA. Until now, she was a guest at the Faculty of Management of the Polish Ministry of Foreign Affairs: Dominika Bettman (president of Siemens Sp.z o.o.) in 2017 and Dorota Warakomska (journalist) in 2018.

The project is implemented in the form of an internship program combined with a series of research and training implemented both in partner enterprises and at the Częstochowa University of Technology.

The project involves the use of the international student exchange program Erasmus + and CEEPUS FREEMOVER, which allow students to study and do internships at European universities and enterprises. The partner enterprises of the program enable them to undertake an internship under the Erasmus + program at their foreign branches. In addition, students (project participants) can count on continuing the internship, and in the future to work in the Polish branches of partner companies. The main assumption is to strengthen the potential of women of virtually all ages who decide to study at the Częstochowa University of Technology. In addition, it will undoubtedly increase the knowledge potential of companies due to the possibility of using the resources of foreign units.

Undertaking professional activity in such an environment requires different characteristics and skills than in a traditional labor market, which in turn requires a different approach to staff training than when training employees for the needs of a traditional economy. The main goal of the project is to identify key competences that will be most relevant in the digital economy. Due to dynamic changes related to the 4.0 economy, employees must be flexible and constantly adapt to new conditions.

The goals of the project are:

1. Identification of key social, professional and technological competences among jobseekers in the voivodeship Silesian related to: knowledge and its application, understanding, critical thinking, problem solving, group work, self-discipline, creativity and entrepreneurship, self-presentation and self-assessment, goal setting, coping with stress, communication and relationships.

2. Creating a competence matrix for individual employers according to the SECTORAL QUALIFICATION FRAMEWORK as one of the elements of the INTEGRATED QUALIFICATION SYSTEM (competency valuation model based 
on the SERVQUAL research model in which the employer's expectations are compared to the experience of employees - Value Competence Matrix) to create a clear career path for plant employees and designing education and training programs that meet the needs of the labor market.

3. Creating comprehensive trainings motivating employees to develop within the organization for effective implementation of the company's goals (in the field of self-presentation, self-motivation, self-discipline.

4. Creating an organizational culture based on a competency-valuing model and a comprehensive training system.

5. Creating a training space based on the results of group work.

6. Activation of both women and men studying at the Częstochowa University of Technology in the context of strengthening their competences and skills on the labor market.

The implementation of the project WiN is associated with many benefits for project partners that result directly from the activities listed below:

1. Organizing an internship or apprenticeship in foreign partner companies for students and graduates (no longer than a year after graduation) supported by the Erasmus + international exchange program and other programs. Implementation period: throughout the duration of the project, cost-free activities for the partner company involving only the appointment of a mentor in the plant where the internship or apprenticeship is carried out.

2. Mentoring - conducting activities supporting the recruitment process, preparation and implementation of the internship program or apprenticeship supported by the Erasmus + program in the form of mentoring related to the preparation of an engineering or master's thesis, as well as the implementation of a doctoral dissertation or an engineering project as part of the classes run by the Department of Production Engineering and Safety at the Faculty of Management, at Częstochowa University of Technology. Implementation period: throughout the duration of the project, non-cost activities for the partner company.

3. A research project focused on creating a matrix of social, professional and technological competences related to: knowledge and its application, understanding, critical thinking, problem solving, group work, self-discipline, creativity, self-presentation and self-assessment, setting goals, coping with stress, communication and relationships. The competency matrix will be based on a model assessing employees 'competences, created on the basis of the SERVQUAL research model, which compares the employer's expectations to the employees' experience and the Value Engineering methodology determining key valuable competences from the company's point of view. It will be a proprietary solution in the form of Value Competence Matrix, whose name will be able to be adapted to the company using this matrix to guarantee the protection of the company's intellectual property. The matrix will serve to create a clear career path for plant employees. Implementation period: March 2020 - December 2020, non-cost activities for the partner company related only to the appointment of a person cooperating with dr inż. R. Stasiak-Betlejewska. This stage involves the commercialization of research results in the form of the development and implementation of a Value Competence Matrix.

4. Designing education and training programs for employees as well as students and graduates consistent not only with the needs of the labor market, but resulting from the created competence matrix. The educational process and training can be implemented, among others: 
4.1. Organization of didactic trips for students of the Faculty of Management at the Częstochowa University of Technology in partner companies.

4.2. Invitation to company employees to take advantage of the education offer as part of the extramural studies of the Faculty of Management.

4.3. Organization of training for partner companies in the Faculty of Management as part of cooperation with the Erasmus + Manager Student Research Club, which at the same time will encourage students to go on internships and internships under the Erasmus + program to foreign units or partner companies.

Trainings conducted at the plant and university in the field of:

- Shaping the image and self-presentation.

- Communications.

- Shaping goals.

- Automation and dealing with negative emotions.

- Self-discipline.

Objective of action: According to current signals from the labor market, there is a need to create comprehensive training motivating employees to develop within the organization for the effective implementation of the company's goals.

Ultimately, the created matrix of competences and the training system will serve the needs of creating an organizational culture in an enterprise that wants to improve not only the product, but also people.

Implementation period: March 2020 - December 2020, non-cost activities for the partner company related only to the appointment of a person cooperating with $\mathrm{dr}$ inż. R. Stasiak-Betlejewska.

This stage involves the commercialization of research results in the form of the development and implementation of short trainings resulting from the analysis of employee competences based on the Value Competence Matrix.

5. The offer of the START + Consultation Point including: the possibility of conducting interviews, training (including in the field of: quality management of products and services, quality management tools, self-presentation, self-motivation, cooperation based on creating innovative solutions) in the company, industrial property protection, project management). Implementation period: throughout the duration of the project, non-cost activities for the partner company.

6. Creating a training space for both students and employees of companies in the Faculty of Management at the START + Consultation Point at the Częstochowa University of Technology. Implementation period: throughout the duration of the project, non-cost activities for the partner company.

7. Organization of conferences and seminars on current management problems occurring in the WiN project partner companies. Implementation period: throughout the duration of the project, non-cost activities for the partner company.

The idea of the WiN mentoring project described above is not only educational or scientific, but above all market-based, as it undoubtedly affects the formation of a positive image of a company entering into cooperation with the Czestochowa University of Technology not only in the country but also on the international arena due to the international scope of the program associated with the Erasmus + program and the possibility of cooperation with foreign branches of companies to which students are sent under internship programs using the international Erasmus + academic exchange programs. 


\section{CONCLUSION}

Managers, i.e. a different generation than female leaders, who sit on company boards, more often emphasize the importance of private life. For them, the success is the acquisition of new competences, achievement of goals and how to achieve them, as well as climbing the career ladder. Leaders, that is women in the highest positions, look at success in many dimensions and do not treat it as the main goal. They emphasize that their success is the success of entire teams of people. As superiors, they want to be taken seriously and be liked. For them, success means self-realization, the ability to reach a compromise, influencing the development of others and a sense of accomplishment.

Survey respondents know that women in senior positions bring new quality to organization management. The natural ability to communicate is one of their advantages. Combined with empathy, it allows you to better integrate teams. According to the interviewed leaders, women are more determined, work harder, assess risk better, and manage time better.

At the same time, they admit that the lack of women in senior positions is a matter of cultural conditions and stereotypes. Men know that they would have to change themselves, because - as they admit - there are behaviors in a highly masculinized group that would be unacceptable in the presence of women.

At the same time, many of our interlocutors know that the current situation will have to change and women will break the glass ceiling. They are aware that the market and management culture must evolve.

\section{Sažetak:}

\section{KLJUČNE ŽENSKE KOMPETENCIJE I NOVA KVALITETA UPRAVLJANJA - SLUČAJ PROJEKTA WIN}

U uvjetima rastuće neizvjesnosti i brzih promjena, suvremenom poslovanju potreban je novi model upravljanja. Stari se temelji na krutoj hijerarhijskoj strukturi te uglavnom na konkurenciji $i$ postizanju pojedinačnih uspjeha. Međutim, izazovi i problemi s kojima se današnje tvrtke suočavaju, zbog svoje složenosti, zahtijevaju novi pristup. Empatija, komunikacijske vještine, otvorenost prema drugima $i$ samosvijest ključni su elementi u izgradnji vodeće pozicije 21. stoljeća. To su takozvane theke"kompetencije, koje se obično percipiraju kao ženske." U radu su predstavljeni rezultati istraživanja ključnih ženskih kompetencija u upravljanju poduzećima, što uključuje $i$ kratku prezentaciju znanstvenog projekta vezanog za suradnju s industrijom na ključnim kompetencijama pod nazivom WiN (Women in NetWork).

Ključne riječi: kvaliteta, kompetencija, upravljanje.

\section{LITERATURE}

1. Bnińska, Maria Kobiety w biznesie. Marzenia a rzeczywistość, Warszawa, maj 2019 r. Copyright by Fundacja Liderek Biznesu, 2019.

2. Kałwa-Rojczyk Anna, Funkcjonowanie turkusowych organizacji w kontekście kompetencji pracowniczych, Studia i Prace WNEIZ US nr 51/2, 2018.

3. Kot, M. (2018), Kompetencje menedżera, Wydawnictwo Helion, Gliwice, pp. $11-12$.

4. Petrovova, Natalia, Only 1 manager out of 3 in the EU is a woman ... ... even less in senior management positions, 43/2019. 
5. Przywództwo przyszłości Polski lider gotowy na zmiany? Raport PwC, Google, Skanska, 2019.

6. Rynek pracy, edukacja, kompetencje. Aktualne trendy i wyniki badań. Marzec 2019, Instytut Analiz Rynku Pracy Sp. z o.o.

7. Stasiak-Betlejewska, Renata Project mentoringowy WiN, Politechnika Częstochowska, 2019.

8. Women in the Workplace 2016. Mc Kinsey\&Company

9. Teow, Jing, Goel, Saloni, Carney, Tara Srestha and Alex Cooper, (2019), Women in Work Index 2019 Turning policies into effective action, PwC, March 2019. 